\title{
Predictive Validity of a DNA Methylation-BASED SCREENING PANEL FOR POSTPARTUM DEPRESSION
}

\section{A PREPRINT}

\author{
Dana M. Lapato* \\ Department of Human and Molecular Genetics \\ Virginia Commonwealth University \\ Richmond, VA 23220 \\ dana.lapato@vcuhealth.org
}

Patricia A. Kinser

Department of Family and Community Health Nursing

Virginia Commonwealth University

Richmond, VA 23220

\author{
Roxann Roberson-Nay \\ Department of Psychiatry \\ Department of Psychology \\ Virginia Commonwealth University \\ Richmond, VA 23220
}

February 21, 2020

\begin{abstract}
Prenatal maternal depression increases the risk of negative maternal-infant health outcomes but often goes unrecognized. As a result, biomarker screening tests capable of identifying women at risk for depression are highly desirable. This study tested how demographic and clinical factors affect the predictive validity of a DNA methylation-based screening test for postpartum major depression (MD) using data from a longitudinal study of birth outcomes. Lifetime history of MD and current levels of postpartum depressive symptoms were assessed using an extended self-report version of the Composite International Diagnostic Interview Short Form and the Edinburgh Postnatal Depression Scale (EPDS), respectively. Predictive validity of the test was estimated in the PREG cohort using the area under the receiver operator characteristic curve (AUC), and sensitivity analyses were performed to assess the impact of self-reported race, age, and pre-pregnancy history of MD. Data for N=103 pregnant participants (African-American=49; European-American=54) were available. The prediction model identified women who would develop high levels of postpartum depressive symptoms better within the subset of women with previous histories of $\mathrm{MD}$ ( $\mathrm{AUC}=0.94,95 \% \mathrm{CI} 0.79-1.00)$ compared to the full pregnant cohort $(\mathrm{AUC}=0.62,95 \% \mathrm{CI} 0.46-0.79)$. This observation prompted secondary analyses to test the model specificity for postpartum depression. The model predicted lifetime history of MD moderately well in never-pregnant, mixed-sex cohort of adolescents $(\mathrm{N}=150$; ages $15-20$; $\mathrm{AUC}=0.75,95 \%$ CI $0.57-0.92$ ) and performed slightly better in males versus females. Additional sensitivity analyses are needed to determine the extent of the model's specificity for MD subtypes and if demographic or clinical factors influence the predictive validity of this model.
\end{abstract}

Keywords DNA methylation - perinatal depression - lifetime depression - screening test - epigenetic biomarker . replication study · PREG study · AYATS

\footnotetext{
${ }^{*}$ Corresponding author
} 
medRxiv preprint doi: https://doi.org/10.1101/2020.03.05.20027847; this version posted March 8, 2020. The copyright holder for this preprint

(which was not certified by peer review) is the author/funder, who has granted medRxiv a license to display the preprint in perpetuity. It is made available under a CC-BY-NC-ND 4.0 International license .

A PREPRINT - FEBRUARY 21, 2020

\section{Introduction}

Maternal depression is one of the most prevalent complications associated with childbirth. ${ }^{1}$ Untreated maternal depression during pregnancy or shortly following birth increases the risk of serious adverse pregnancy, maternal, and infant-child outcomes, even if the depressive symptoms do not reach established diagnostic thresholds. 1/2]3/4 Treatment for maternal depression during pregnancy can significantly reduce the odds of negative health consequences. 45 As a result, identifying pregnant women at elevated risk for or currently experiencing maternal depression is a critical focal point for developing perinatal health interventions. Efforts to raise awareness of perinatal-onset MD have included the addition of a specifier to the fifth edition of the Diagnostic and Statistical Manual (DSM-5) and updated perinatal depression screening guidelines from the American College of Obstetricians and Gynecologists (ACOG). Despite these changes, recognizing MD episodes and depressive symptoms during pregnancy and the early postpartum remains challenging. Patients and clinicians alike may struggle to determine if the constellation of symptoms reflects classic somatic indicators of MD (e.g., changes in weight/appetite, difficulty sleeping, and fatigue) or benign pregnancy-related physiological and/or hormonal changes. 6

Given the challenges of assessing maternal perinatal depressive psychopathology, biomarker-based screening tests capable of indexing risk for perinatal-onset MD could prove invaluable for reducing the number of unrecognized cases of maternal depression. DNA methylation (DNAm) has become a prominent biomarker candidate, in part because it is easily measured in peripheral blood and its patterning can be influenced by both genetic and environmental factors. ${ }^{78|8| 9 \mid 10}$ DNAm is a chemical modification to DNA that can influence gene expression and genomic stability without altering the DNA sequence. In 2014, two DNAm sites near TTC9B and HP1BP3 were associated with postpartum depression (PPD) and acheived high levels of clinical predictive accuracy. $\frac{11}{11}$ Follow-up analyses of related biomarkers have been performed in other cohorts, $\frac{12}{12}$ including assessments of gene expression and postpartum DNAm remodeling trajectories of the loci near TTC9B and HPIBP3. Due to the potential importance of the original finding, replication studies in independent cohorts and additional sensitivity analyses should be performed to assess the generalizability of the prediction algorithm. So far, the tested cohorts have been composed predominantly of participants who self-identified as Caucasian, were in their early 30's, and had a significant histories of either MD or bipolar disorder (see Table 2). As a result, the impact of genetic ancestry, maternal age, and maternal history of psychopathology on the predictive validity of the DNAm biomarkers is unclear.

The current study builds on initial findings by assessing the predictive validity and generalizability of the DNAm biomarker model in an epidemiological cohort of pregnant women from the Pregnancy, Race, Environment, Genes (PREG) study. ${ }^{13}$ During the analysis, the high accuracy estimates were replicated for PPD risk, but only in a subset of participants with a lifetime history of MD. This observation motivated a specificity test of the prediction model to determine if the biomarkers associated uniquely with pregnancy-related depression. This analysis was carried out in a mixed-sex, never-pregnant subset of adolescent participants from the Adolescent and Young Adult Twin Study (AYATS).

\section{Methods}

\subsection{Preregistation}

The replication analysis was preregistered on the Open Science Framework (OSF) ${ }^{14}$ using the AsPredicted format. The preregistration document and $\mathrm{R}$ code used to analyze the data and generate figures are available on the Open Science Framework (https://osf.io/7dsf9).

\subsection{Samples}

\subsubsection{Pregnancy, Race, Environment, Genes (PREG) Study}

The Pregnancy, Race, Environment, Genes (PREG) Study was a prospective longitudinal study that followed approximately 230 women over the course of pregnancy. ${ }^{13}$ Participants completed extensive questionnaires about lifetime and current exposure to social and environmental determinants of health up to four times during pregnancy. Peripheral blood was collected at each visit and used for DNAm analysis. Additional funding secured in the second year of the PREG study permitted enrolling approximately 100 of the participants into a postpartum extension that included two additional time points. Study enrollment criteria included 1) maternal age between 18 and 40 years old, 2) no use of artificial reproductive technology, 3) absence of diabetes, and 4) both parents had to self-identify as either EuropeanAmerican or African-American. Exclusion criteria at birth included any congenital, placental, or amniotic abnormalities (e.g., chromosomal abnormalities, polyhydramnios), preeclampsia/ PIH (pregnancy induced hypertension)/ HELLP 
medRxiv preprint doi: https://doi.org/10.1101/2020.03.05.20027847; this version posted March 8, 2020. The copyright holder for this preprint

(which was not certified by peer review) is the author/funder, who has granted medRxiv a license to display the preprint in perpetuity.

It is made available under a CC-BY-NC-ND 4.0 International license .

A PREPRINT - FEBRUARY 21, 2020

(hemolysis, elevated liver enzymes, low platelet count), Rh sensitization, cervical cerclage, medically necessitated preterm delivery, drug abuse, and participating in fewer than 3 study time point assessments (including birth).

\subsubsection{Adolescent and Young Adult Twin Study (AYATS)}

The Adolescent and Young Adult Twin Study (AYATS) is a longitudinal study that enrolled a general population sample of monozygotic (MZ) and dizygotic twin pairs between the ages of $15-20$ years old $\cdot{ }^{15}$ Comprehensive questionnaires about mood and lifetime history of psychopathology were collected along with peripheral blood. DNAm was assayed on a subset of MZ twin pairs ( $\mathrm{N}=75$ pairs, $\mathrm{N}=150$ twins, $73 \%$ female) selected based on pair status for lifetime MD (i.e., concordant positive, concordant negative, and discordant). No participants selected for DNAm measurement were using or had used antidepressant medication or medication with psychotropic effects for at least one month prior to providing a blood sample. Demographic information for the full AYATS sample and the DNAm subset are available elsewhere. 15116

\subsection{Depression phenotypes}

Lifetime history of $M D$ was measured using a self-report version of the Composite International Diagnostic InterviewShort Form (CIDI-SF) ${ }^{17}$ In both the PREG study and AYATS, MD was considered present if at least four Criterion A symptoms, which had to include sad mood and/or anhedonia, were endorsed as present every day or nearly everyday, for the entire day or most of the day for two weeks. Additionally, participants had to endorse that the presence of the depression symptoms caused considerable distress or functional impairment. The use of a slightly lower threshold for defining clinical MD has been implemented previously and was justified given the that 1) participants must rely on retrospective memory and 2) that participants with four symptoms are phenotypically closer to a case (defined in the DSM-5 as the presence of at least five Criterion A symptoms in addition to interference ${ }^{18}$ ) than a control. $\frac{1611920}{16}$ Lifetime history of MD was assessed in both cohorts during the initial study visit. Use of antidepressant medication was not assessed in the PREG study.

Current level of perinatal depressive symptoms was assessed in PREG at postpartum study visits using the Edinburgh Postnatal Depression Scale (EPDS) between 1 and 3 months postpartum. 21 The EPDS is the most frequently used validated clinical tool to assess perinatal depressive symptoms. ${ }^{22233}$ Participants with EPDS scores of $\geq 13$ were considered likely postpartum depression (PPD) cases. ${ }^{21 / 24}$ Perinatal depressive symptoms were not assessed in AYATS because history of pregnancy was an exclusion criterion. 15

\subsection{DNAm measurement and processing}

Genome-wide DNAm was measured in both studies using the Illumina Infinium HumanMethylation450 microarray. Raw files were processed independently for each cohort in the R environment using Bioconductor packages. 255262728 Poor quality specimens were identified and removed before quantile normalization. Blood cell proportions were estimated using the Houseman method ${ }^{29}$ consistent with the original study. ${ }^{11} \mathrm{M}$-values were used for all analyses, and sensitivity analyses were performed with beta values to ensure that that data transformation did not affect the results. For all PREG participants, the DNAm sample from the first prenatal study visit was used since a previous study has shown the putative relationship between DNAm and postpartum depressive psychopathology is stronger in the first trimester compared to the third trimester. ${ }^{12}$ ComBat was used to adjust for slide effects. ${ }^{30}$

\subsection{Statistical analysis}

All analyses were performed in the R statistical environment using the pROC package. ${ }^{[25] 31}$ The predictive formula from Guintivano (2014) is defined in Osborne (2016) as:

$$
\mathrm{PPD} \sim \text { cg21326881 + cell ratio + (cell ratio*cg21326881) + cg00058938 }
$$

where PPD is a dichotomous outcome defined as the presence of postpartum MDP, cell ratio is the ratio of the estimated proportion of monocytes compared to the estimated proportions of CD4T cells, CD8T cells, B cells, and granulocytes (natural killer cells not listed as part of the calculation ${ }^{12}$ ), and $\operatorname{cg} 21326881$ and $\operatorname{cg} 00058938$ representing the beta values of DNAm probe sites near the genes $H P 1 B P 3$ and TTC $9 B$, respectively. The coefficients for the model were not reported in either paper.

Area under the receiver operator characteristic curves (AUC, ROC) was calculated for the full PREG sample to assess the model's accuracy, and subsets of the PREG sample were modeled separately to test if the predictive validity of the model was influenced by demographic (e.g., age, self-identified Census-based race category) and clinical (e.g., lifetime history of depressive psychopathology) factors. Confidence intervals were calculated via bootstapping ( $\mathrm{k}=2000)$. 
medRxiv preprint doi: https://doi.org/10.1101/2020.03.05.20027847; this version posted March 8, 2020. The copyright holder for this preprint

(which was not certified by peer review) is the author/funder, who has granted medRxiv a license to display the preprint in perpetuity. It is made available under a CC-BY-NC-ND 4.0 International license .

A PREPRINT - FEBRUARY 21, 2020

Secondary analyses designed to test model specificity for pregnancy-related MD were structured so that lifetime history of MD (instead of perinatal depressive symptom load) was the predictor. The data used for this analysis came from AYATS. ${ }^{15}$ To avoid bias from multiple genetically identical individuals, the AYATS sample was divided by twin order so that each group only had genetically distinct participants. The groups were further subdivided by sex to determine if the model could work in males.

\section{Results}

\subsection{Study demographics}

The PREG study had N=103 participants (African-American $=49$; European-American $=54$, mean age $=29.6$ years (sd $=4.5$ years)) with prenatal DNAm and postpartum EPDS measures. The average EPDS score was 5.4, and 17.5\% of women endorsed a positive lifetime history of MD. Neither MD history nor EPDS score was significantly associated with gestational age at delivery. The AYATS sample included $\mathrm{N}=150$ participants (75 MZ European-American twin pairs, $72 \%$ female, mean age $=17.0$ years $(\mathrm{sd}=1.3$ years $)$ ). Approximately $26 \%$ of the participants endorsed a lifetime history of MD (mean age of onset 14.7 years).

\subsection{Predictive accuracy}

Summary information for all models tested with the PREG study and AYATS can be found in Table 1] The predictive strength of the algorithm was modest (AUC: 0.62 [CI:0.45-0.79] in the full PREG sample; Figure 1a), and increasing the EPDS threshold to 15 did not improve the AUC; however, the algorithm exhibited high accuracy predicting high postpartum depressive symptom load in the subset of PREG participants with a lifetime history of MD (AUC:0.94 [CI:0.79-1.00]; Figure 1b). Sensitivity analyses in the full PREG sample and the African-American subset suggest that the accuracy of the algorithm for predicting high postpartum depressive symptom load within the first seven months postpartum may not be strongly affected by age. While the AUC point estimates for the older subset of the full PREG sample and the African-American subsets are larger than those for the younger subsets, the $95 \%$ confidence intervals ( $95 \%$ CI) overlap substantially ( 0.83 [95\% CI: $0.59-.90$ ] versus 0.74 [95\% CI: $0.55-0.93$ ] and 0.83 [95\% CI: $0.63-1.00$ ] and 0.78 [95\% CI: 0.56-0.99] for the full sample and African-American subset, respectively).

The biomarker model demonstrated similar levels of accuracy for predicting lifetime history of MD in men using data from AYATS (0.83 [95\% CI: 0.63-1.00]; average between twin 1 (T1) and twin 2 (T2) compared to the replication attempt using data from the Franconian Maternal Health Evaluation Studies (FRAMES; 0.81 [95\% CI: 0.68-0.93]); 32 ] however, the AUC estimates were lower for predicting lifetime history of MD in adolescent females, and the $95 \%$ CIs for one subset of female twins included 0.50 (see Table 1 ).

\section{Discussion}

The purpose of these analyses were to assess the generalizability, predictive validity, and specificity of a DNAm-based model for prospectively predicting PPD from prenatal maternal blood. Collectively, the findings suggest the model identified individuals who have a positive lifetime history of MD and, for those individuals, can predict who will go on to develop postpartum depression. Further, the results suggest that the model may not be specific to pregnancy-related depression. Reasonably high AUC point estimates were obtained from a ROC analysis for both the male and female subsets of AYATS participants ( 0.85 and 0.74 , respectively). Taken together, it is possible that the model correctly identifies women at risk for high levels of postpartum depression because those are the women with the greatest severity of lifetime MD. It also is possible that this model works especially well in individuals with a history of MD. In hindsight, a careful review of previous work developing and testing this model further supports the notion that the biomarker model may be primed to work best in individuals with a history of depressive psychopathology. First, the DNAm biomarkers were selected based on their joint predictive power in a clinical sample of participants with histories of either major depression or bipolar disorder (BP). 111 This clinical bias continued in the replication study, which used primarily cohorts enriched for depressive psychopathology (i.e., the Genetics of Recurrent Early Onset Depression (GenRED; 33 50\% MD) and the Prospective Gene Expression Postpartum Cohort from the Emory Women's Mental Health Program 34 ( $60 \%$ MD, 40\% BP; see Table 2. ${ }^{12}$ Second, the analyses of DNAm remodeling trajectories in the Franconian Maternal Health Evaluation Studies (FRAMES) ${ }^{35}$ and GenRED suggest that women with a history of PPD follow distinctly different DNAm patterns over time in both samples. This observation suggests that experiencing an episode of PPD may lead to subsequent epigenetic scarring in genomic regions associated with hormone responsiveness. It is possible that similar kinds of DNAm scars occur as a result of non-pregnancy-related MD episodes. Taken together, these results cumulatively support the hypothesis that MD episodes can evoke chronic perturbances in the DNA methylome and that 
medRxiv preprint doi: https://doi.org/10.1101/2020.03.05.20027847; this version posted March 8, 2020. The copyright holder for this preprint

(which was not certified by peer review) is the author/funder, who has granted medRxiv a license to display the preprint in perpetuity. It is made available under a CC-BY-NC-ND 4.0 International license .

A PREPRINT - FEBRUARY 21, 2020

interindividual variation in DNAm changes may explain why some women with a history of MD are at greater risk to develop PPD compared to other women with previous MD episodes.

It remains unclear if the DNAm values at these sites reflect risk for postpartum depression, a consequence of prior depressive episodes, a mixture of both, or something else entirely that correlates with risk for MD. More work is needed to understand the biological pathways and functional consequences associated with DNA methylation states at these two genomic loci. Carefully constructed longitudinal prospective studies will be necessary to disentangle the direction of causation between MD episodes that onset before, during, and after pregnancy and the DNA methylation patterns and remodeling associated with each. Addressing these questions along with concerns about generalizability across age and ethnicities is a critical step to applying this research to clinical practice. An accurate predictive algorithm for perinatal depression could have major implications for maternal-offspring health. Both perinatal depression and subclinical perinatal depressive symptoms have been associated with adverse maternal-infant health outcomes ${ }^{4}$ Recognizing maternal depression during pregnancy can be difficult due to the overlap between somatic signs of depression and typical pregnancy feelings/experiences (e.g., difficulty sleeping, changes in appetite), which is precisely why a biomarker test would be invaluable.

The strengths of this study include its prospective sampling of DNAm and multiple measures of depressive psychopathology. Moreover, the PREG study is demographically diverse in that it includes both African-American and European-American women from a wide range of ages (18-40) and pregnancy histories. Furthermore, data from a modest sample of never-pregnant adolescent participants was included to test if an episode of early-onset MD in the absence of any pregnancy was sufficient to be identified by the predictive algorithm. Additionally, the main analyses of this work were preregistered, which enables readers to distinguish planned tests from posthoc follow up analyses. However, the results should be considered in the context of study limitations. Most importantly, the replication analysis centers on using the general model described in Osborne (2016); however, without the the same coefficients that were used in that analysis, the exact model cannot be tested here. Secondly, the two samples used in these analyses (especially the twin sample) were of modest size, which contributed to large confidence intervals around AUC estimates. Also, both studies relied on a self-report version of the CIDI-SF to assess lifetime history of depressive psychopathology, and the PREG study used the EPDS to assess current levels of perinatal depressive symptoms. While self-report instruments have been associated with inflated estimates of MDP prevalence, there is evidence that EPDS is one of a few self-report instruments that has good sensitivity and specificity but does not overestimate the prevalence of perinatal depressive episodes meeting clinical thresholds compared to structured clinical interviews. ${ }^{36}$ This detail is important because it suggests that using the EPDS may mitigate the issue of misclassification. Finally, antidepressant medication use was not assessed in the PREG cohort. That said, in both the original ${ }^{11}$ and replication ${ }^{12}$ studies, antidepressant use did not affect the AUC estimates of the algorithm's predictive validity.

\section{Declarations}

The authors have no conflicts of interest to declare.

\subsection{Acknowledgements}

The Pregnancy, Race, Environment, Genes (PREG) longitudinal study and its postpartum extension were supported by the NIHMD (P60MD002256, PI: York, Strauss), The John and Polly Sparks Foundation and Brain and Behavior Research Foundation (24712, PI: York), American Nurses Foundation Research Grant (5232, PI: Kinser), Virginia Commonwealth University Center for Clinical and Translational Research Endowment Fund (6-40595, PI: Kinser). The Adolescent and Young Adult Twin Study was supported by a NARSAD Independent Investigator Award from the Brain and Behavior Research Foundation and by the NIMH (R01MH101518) to RRN. DL is supported by NIMH T32MH020030 (PI: M. Neale). Both studies used REDCap to administer self-report questionnaires, and the use of REDCap was supported by Clinical and Translational Science Award (CTSA) award No. UL1TR000058 from the National Center for Advancing Translational Sciences. Its contents are solely the responsibility of the authors and do not necessarily represent official views of the National Center for Advancing Translational Sciences or the National Institutes of Health.

\subsection{Informed consent and study approval}

The Virginia Commonwealth University Institutional Review Board (VCU IRB) approval and written participant consent was established for both the PREG study (14000) and AYATS (HM15348). Written parental consent was obtained for AYATS participants who were under the age of 18 years old. 
medRxiv preprint doi: https://doi.org/10.1101/2020.03.05.20027847; this version posted March 8, 2020. The copyright holder for this preprint (which was not certified by peer review) is the author/funder, who has granted medRxiv a license to display the preprint in perpetuity.

It is made available under a CC-BY-NC-ND 4.0 International license.

A PREPRINT - FEBRUARY 21, 2020

\subsection{Data sharing}

The preregistration document and $\mathrm{R}$ code used to analyze the data and generate figures is available on the Open Science Framework (OSF) project landing page (https://osf.io/7dsf9). Data sharing from the Pregnancy, Race, Environment, Genes (PREG) study and Adolescent and Young Adult Twin Study are limited by Institutional Review Board (IRB) agreements and participant consent forms, which restrict openly sharing individual-level DNA methylation measures. Individuals interested in PREG or AYATS data access or collaboration are encouraged to contact Dr. Timothy P. York (timothy.york@ vcuhealth.org) or Dr. Roxann Roberson-Nay (roxann.robersonnay@ vcuhealth.org), respectively.

\subsection{Author contributions}

DL planned and carried out the analysis and wrote the initial manuscript draft. TPY and PK conceived of and secured funding for the Pregnancy, Race, Environment, Genes (PREG) study and the postpartum extension study, respectively. RRN conceived of the Adolescent and Young Adult Twin Study (AYATS). All co-authors reviewed the manuscript and approved the final version.

\subsection{Conflicts of interest}

The authors regretfully report that they have no conflicts of interest.

\subsection{Abbreviations}

AUC Area under the curve

AYATS Adolescent and Young Adult Twin Study

DNAm DNA methylation

EPDS Edinburgh Postnatal Depression Scale

MD Major depression

MDP Major depression in the peripartum

MZ Monozygotic

PPD Postpartum depression

PREG Pregnancy, Race, Environment, Genes Study

ROC Receiver operator characteristic 
medRxiv preprint doi: https://doi.org/10.1101/2020.03.05.20027847; this version posted March 8, 2020. The copyright holder for this preprint (which was not certified by peer review) is the author/funder, who has granted medRxiv a license to display the preprint in perpetuity.

It is made available under a CC-BY-NC-ND 4.0 International license .

\section{Figures}

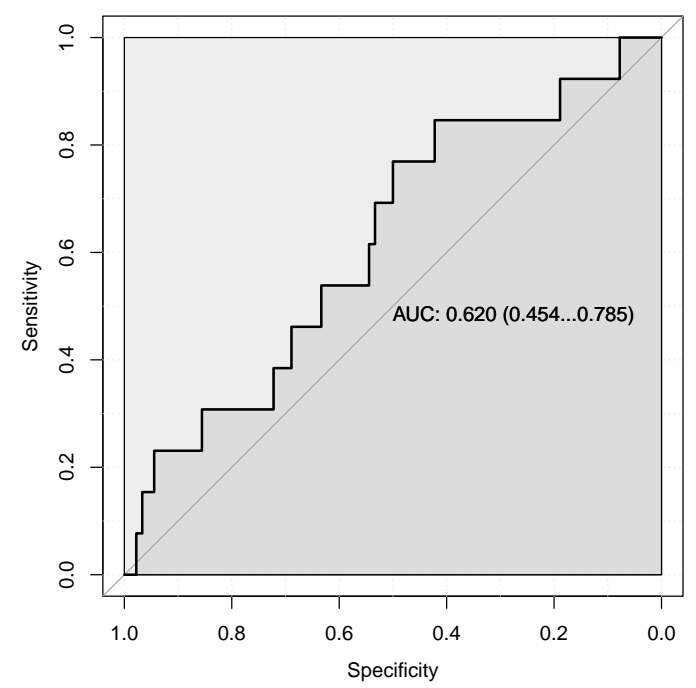

(a) Full Sample

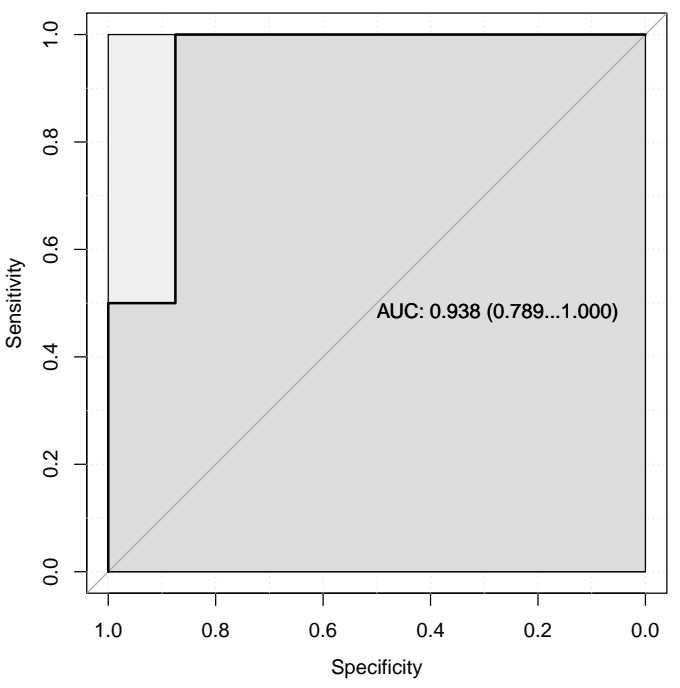

(b) Lifetime MD+

Figure 1: Area under the receiver operator characteristic curve predicting probable postpartum depression in PREG. The algorithm performed significantly better in the subset of PREG participants who endorsed having a positive lifetime history of major depression (MD) (1b) compared to the full PREG sample [1a).

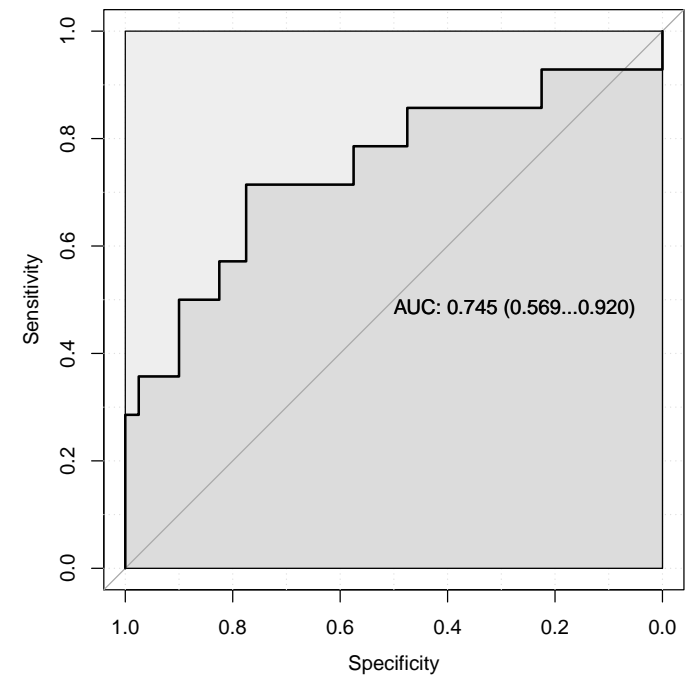

Figure 2: Area under the receiver operator characteristic curve predicting lifetime history of major depression in female participants from the AYATS sample. 
medRxiv preprint doi: https://doi.org/10.1101/2020.03.05.20027847; this version posted March 8, 2020. The copyright holder for this preprint (which was not certified by peer review) is the author/funder, who has granted medRxiv a license to display the preprint in perpetuity.

It is made available under a CC-BY-NC-ND 4.0 International license .

A PREPRINT - FEBRUARY 21, 2020

\section{Tables}

Table 1: Model Results

\begin{tabular}{rllrrrl}
\hline Study & Subsample & Outcome & $\mathrm{N}$ & Age & AUC & CI \\
\hline PREG & + Life hx & EPDS & 18 & 31.11 & 0.94 & $0.79-1$ \\
AYATS & T1 (M) & Lifetime MD & 21 & 16.67 & 0.85 & $0.68-1$ \\
PREG & $>28$ yo (AA) & EPDS & 18 & 33.50 & 0.83 & $0.63-1$ \\
AYATS & T2 (M) & Lifetime MD & 21 & 16.67 & 0.81 & $0.58-1$ \\
PREG & $<29$ yo (AA) & EPDS & 31 & 24.81 & 0.78 & $0.56-0.99$ \\
PREG & $>28$ yo & EPDS & 60 & 32.78 & 0.75 & $0.59-0.9$ \\
PREG & $<29$ yo & EPDS & 43 & 25.28 & 0.74 & $0.55-0.93$ \\
AYATS & T1 (F) & Lifetime MD & 54 & 17.07 & 0.74 & $0.57-0.92$ \\
PREG & EA only & EPDS & 54 & 31.15 & 0.72 & $0.42-1$ \\
AYATS & T1 only & Lifetime MD & 75 & 16.96 & 0.72 & $0.57-0.86$ \\
AYATS & T2 (F) & Lifetime MD & 54 & 17.07 & 0.67 & $0.48-0.85$ \\
PREG & $>28$ yo (EA) & EPDS & 42 & 32.48 & 0.66 & $0.32-1$ \\
AYATS & T2 only & Lifetime MD & 75 & 16.96 & 0.66 & $0.52-0.81$ \\
PREG & AA only & EPDS & 49 & 28.00 & 0.65 & $0.45-0.85$ \\
PREG & Full Sample & EPDS & 103 & 29.65 & 0.62 & $0.45-0.79$ \\
\hline
\end{tabular}

Abbreviations. $\mathrm{AUC}=$ area under the curve, $\mathrm{CI}=95 \%$ confidence interval, MD = major depression, EPDS = Edinburgh Postnatal Depression Scale, + Life $\mathrm{hx}=$ positive lifetime history of $\mathrm{MD}, \mathrm{T} 1=$ Twin $1, \mathrm{~T} 2=$ Twin $2, \mathrm{AA}=$ African-American, EA = European-American, $\mathrm{M}=$ Male, $\mathrm{F}=$ Female. 
Table 2: Comparison of Current Analysis with Previous Studies of the Postpartum Depression Predictive Algorithm

\begin{tabular}{|c|c|c|c|c|c|c|c|}
\hline Cohort & $\mathrm{N}$ & Age, M(sd) & Race & $\mathrm{MD} / \mathrm{BP}(\%)$ & DNAm timeframe & $\begin{array}{l}\text { Postpartum } \\
\text { MD/Dsx }\end{array}$ & Instrument \\
\hline PREG PPD & 103 & $29.6(4.5)$ & $\begin{array}{l}52.4 \% \text { Caucasian } \\
\text { 47.6\% African American }\end{array}$ & $17.5 / *$ & Early pregnancy & $\leq 7$ months & EPDS \\
\hline AYATS & 150 & $17.5(1.28)$ & $100 \%$ Caucasian & $26 / 0$ & Nulligravida & NA & CIDI-SF ${ }^{1}$ \\
\hline JHU PPD Cohort & $93^{2}$ & $30.6(6.3)$ & $70 \%$ Caucasian & $\sim 66 / \sim 33$ & Prenatal & 1 month & Psychiatric interview \\
\hline GenRED & 84 & $39.7(.09)$ & $\begin{array}{l}92 \% \text { Caucasian } \\
1.2 \% \text { African American } \\
1.2 \% \text { Asian } \\
3.6 \% \text { Unreported }\end{array}$ & $44.6 / 2.4$ & $\begin{array}{l}\text { Postpartum; } \\
\text { Time since delivery unclear }\end{array}$ & Unclear & Unclear \\
\hline FRAMES & 240 & $32.7(.02)$ & $100 \%$ Caucasian & $* / *$ & 1-3 years postpartum & 6-8 months & HDRS \\
\hline Emory PPD Cohort & 62 & 33 & $\sim 85 \%$ Caucasian & $59.6 / 40.6$ & Prenatal & Postpartum & HDRS \\
\hline
\end{tabular}

$*$ Not assessed
1 An extended self-report version of the CIDI-SF was used to assess lifetime history of MD.

Race is based on self-identified Census-based race categories. DNAm and Postpartum MD/Dsx columns show time of blood sample collection and psychiatric assessment, respectively, relative to birth.

2 The Guintivano (2014) paper describes the cohort as including 93 recruited women and analyses that involved 51 women. To the best of our knowledge, the clinical and demographic proportions listed in the paper refer to the recruited cohort.

Abbreviations. MD = major depression; BP = bipolar disorder; DNAm = DNA methylation; Dsx = depressive symptoms; NA = Not applicable; PREG PPD = Pregnancy, Race, Environment, Genes Study Postpartum Extension; EPDS = Edinburgh Postnatal Depression Scale; AYATS=Adolescent and Young Adult Twin Study; CIDI-SF = Composite International Diagnostic Interview-Short Form; JHU PPD Cohort = Johns Hopkins Prospective Postpartum Cohort 11 , GenRED=Genetics of Recurrent Early Onset Depression; FRAMES = Franconian Maternal Health Evaluation Studies; Emory PPD Cohort=Prospective Gene Expression Postpartum Cohort from the Emory Women's Mental Health Program 34 
medRxiv preprint doi: https://doi.org/10.1101/2020.03.05.20027847; this version posted March 8, 2020. The copyright holder for this preprint

(which was not certified by peer review) is the author/funder, who has granted medRxiv a license to display the preprint in perpetuity. It is made available under a CC-BY-NC-ND 4.0 International license .

A PREPRINT - FEBRUARY 21, 2020

\section{References}

[1] Nancy W Selix and Deepika Goyal. Recent Policy Changes in Perinatal Depression Screening and Treatment. The Journal for Nurse Practitioners, 14(2):117-123, feb 2018. ISSN 1555-4155. doi: 10.1016/j.nurpra.2017.11.016. URL https ://doi.org/10.1016/j.nurpra.2017.11.016.

[2] Christina L Wichman and Theodore A Stern. Diagnosing and Treating Depression During Pregnancy. The primary care companion for CNS disorders, 17(2):10.4088/PCC.15f01776, apr 2015. ISSN 2155-7772. doi: 10.4088/PCC. 15f01776. URL https://www.ncbi.nlm.nih.gov/pubmed/26445696https://www.ncbi.nlm.nih.gov/ pmc/PMC4560196/

[3] Sophie Grigoriadis, Emily H VonderPorten, Lana Mamisashvili, George Tomlinson, Cindy-Lee Dennis, Gideon Koren, Meir Steiner, Patricia Mousmanis, Amy Cheung, Kim Radford, Jovana Martinovic, and Lori E Ross. The impact of maternal depression during pregnancy on perinatal outcomes: a systematic review and metaanalysis. The Journal of clinical psychiatry, 74(4):e321-41, apr 2013. ISSN 1555-2101 (Electronic). doi: 10.4088/JCP.12r07968.

[4] Michael J Meaney. Perinatal Maternal Depressive Symptoms as an Issue for Population Health. The American journal of psychiatry, 175(11):1084-1093, aug 2018. ISSN 1535-7228 (Electronic). doi: 10.1176/appi.ajp.2018. 17091031.

[5] Elizabeth O'Connor, Rebecca C Rossom, Michelle Henninger, Holly C Groom, and Brittany U Burda. Primary Care Screening for and Treatment of Depression in Pregnant and Postpartum Women: Evidence Report and Systematic Review for the US Preventive Services Task Force. JAMA, 315(4):388-406, jan 2016. ISSN 1538-3598 (Electronic). doi: 10.1001/jama.2015.18948.

[6] A Whitton, R Warner, and L Appleby. The pathway to care in post-natal depression: women's attitudes to post-natal depression and its treatment. The British journal of general practice: the journal of the Royal College of General Practitioners, 46(408):427-428, jul 1996. ISSN 0960-1643. URL https://www.ncbi.nlm.nih gov/pubmed/8776916https://www.ncbi.nlm.nih.gov/pmc/articles/PMC1239697/.

[7] Peter A Jones. Functions of DNA methylation: islands, start sites, gene bodies and beyond. Nature reviews. Genetics, 13(7):484-92, 2012. ISSN 1471-0064. doi: 10.1038/nrg3230. URL http://www.ncbi.nlm.nih. gov/pubmed/22641018

[8] Torsten Klengel, Divya Mehta, Christoph Anacker, Monika Rex-Haffner, Jens C Pruessner, Carmine M Pariante, Thaddeus W W Pace, Kristina B Mercer, Helen S Mayberg, Bekh Bradley, Charles B Nemeroff, Florian Holsboer, Christine M Heim, Kerry J Ressler, Theo Rein, and Elisabeth B Binder. Allele-specific FKBP5 DNA demethylation mediates gene-childhood trauma interactions. Nature neuroscience, 16(1):33-41, jan 2013. ISSN 1546-1726 (Electronic). doi: 10.1038/nn.3275.

[9] Bonnie R Joubert, Siri E Håberg, Douglas A Bell, Roy M Nilsen, Stein Emil Vollset, Øivind Midttun, Per Magne Ueland, Michael C Wu, Wenche Nystad, Shyamal D Peddada, and Stephanie J London. Maternal smoking and DNA methylation in newborns: In utero effect or epigenetic inheritance? Cancer epidemiology, biomarkers \& prevention : a publication of the American Association for Cancer Research, cosponsored by the American Society of Preventive Oncology, 23(6):1007-1017, jun 2014. ISSN 1055-9965. doi: 10.1158/1055-9965.EPI-13-1256. URL http://www.ncbi.nlm.nih.gov/pmc/articles/PMC4140220/.

[10] Ai Ling Teh, Hong Pan, Li Chen, Mei Lyn Ong, Shaillay Dogra, Johnny Wong, Julia L. MacIsaac, Sarah M. Mah, Lisa M. McEwen, Seang Mei Saw, Keith M. Godfrey, Yap Seng Chong, Kenneth Kwek, Chee Keong Kwoh, Shu E. Soh, Mary F F Chong, Sheila Barton, Neerja Karnani, Clara Y. Cheong, Jan Paul Buschdorf, Walter Stünkel, Michael S. Kobor, Michael J. Meaney, Peter D. Gluckman, and Joanna D. Holbrook. The effect of genotype and in utero environment on interindividual variation in neonate DNA methylomes. Genome Research, 24(7): 1064-1074, 2014. ISSN 15495469. doi: 10.1101/gr.171439.113.

[11] J Guintivano, M Arad, T D Gould, J L Payne, and Z A Kaminsky. Antenatal prediction of postpartum depression with blood DNA methylation biomarkers. Molecular psychiatry, 19(5):560-567, may 2014. ISSN 1476-5578 (Electronic). doi: 10.1038/mp.2013.62.

[12] Lauren Osborne, Makena Clive, Mary Kimmel, Fiona Gispen, Jerry Guintivano, Tori Brown, Olivia Cox, Jennifer Judy, Samantha Meilman, Aviva Braier, Matthias W Beckmann, Johannes Kornhuber, Peter A Fasching, Fernando Goes, Jennifer L Payne, Elisabeth B Binder, and Zachary Kaminsky. Replication of Epigenetic Postpartum Depression Biomarkers and Variation with Hormone Levels. Neuropsychopharmacology : official publication of the American College of Neuropsychopharmacology, 41(6):1648-1658, may 2016. ISSN 1740-634X (Electronic). doi: 10.1038/npp.2015.333.

[13] Dana M Lapato, Sara Moyer, Emily Olivares, Ananda B Amstadter, Patricia A Kinser, Shawn J Latendresse, Colleen Jackson-Cook, Roxann Roberson-Nay, Jerome F Strauss, and Timothy P York. Prospective longitudinal 
medRxiv preprint doi: https://doi.org/10.1101/2020.03.05.20027847; this version posted March 8, 2020. The copyright holder for this preprint

(which was not certified by peer review) is the author/funder, who has granted medRxiv a license to display the preprint in perpetuity. It is made available under a CC-BY-NC-ND 4.0 International license .

A PREPRINT - FEBRUARY 21, 2020

study of the pregnancy DNA methylome: the US Pregnancy, Race, Environment, Genes (PREG) study. BMJ open, 8(5):e019721, may 2018. ISSN 2044-6055 (Electronic). doi: 10.1136/bmjopen-2017-019721.

[14] Erin D Foster and Ariel Deardorff. Open Science Framework (OSF). Journal of the Medical Library Association : $J M L A$, 105(2):203-206, apr 2017. ISSN 1536-5050. doi: 10.5195/jmla.2017.88. URL https://www.ncbi.nlm. nih.gov/pmc/articles/PMC5370619/https://www.ncbi.nlm.nih.gov/pmc/PMC5370619/.

[15] Jennifer L Cecilione, Lance M Rappaport, Shannon E Hahn, Audrey E Anderson, Laura E Hazlett, Jason R Burchett, Ashlee A Moore, Jeanne E Savage, John M Hettema, and Roxann Roberson-Nay. Genetic and Environmental Contributions of Negative Valence Systems to Internalizing Pathways. Twin research and human genetics : the official journal of the International Society for Twin Studies, 21(1):12-23, feb 2018. ISSN 1832-4274 (Print). doi: 10.1017/thg.2017.72.

[16] Roxann Roberson-Nay, Aaron R Wolen, Dana M Lapato, Eva E Lancaster, Bradley T Webb, Brad Verhulst, John M Hettema, and Timothy P York. Twin Study of Early-Onset Major Depression Finds DNA Methylation Enrichment for Neurodevelopmental Genes. bioRxiv, jan 2018. URL http://biorxiv.org/content/early/ 2018/11/01/422345.

[17] Ronald C Kessler and T Bedirhan Ustun. The World Mental Health (WMH) Survey Initiative Version of the World Health Organization (WHO) Composite International Diagnostic Interview (CIDI). International journal of methods in psychiatric research, 13(2):93-121, 2004. ISSN 1049-8931 (Print).

[18] American Psychiatric Association. Diagnostic and statistical manual of mental disorders. American Psychiatric Publishing, Inc., Arlington, VA, US, fifth edition, 2013. ISBN 9780890425541. doi: 10.1176/appi.books. 9780890425596.744053.

[19] K S Kendler, M C Neale, R C Kessler, A C Heath, and L J Eaves. A population-based twin study of major depression in women. The impact of varying definitions of illness. Archives of general psychiatry, 49(4):257-266, apr 1992. ISSN 0003-990X (Print).

[20] R L Spitzer, J Endicott, and E Robins. Research diagnostic criteria: rationale and reliability. Archives of general psychiatry, 35(6):773-782, jun 1978. ISSN 0003-990X (Print).

[21] J L Cox, J M Holden, and R Sagovsky. Detection of postnatal depression. Development of the 10-item Edinburgh Postnatal Depression Scale. The British journal of psychiatry : the journal of mental science, 150:782-786, jun 1987. ISSN 0007-1250 (Print).

[22] Veerle Bergink, Libbe Kooistra, Mijke P Lambregtse-van den Berg, Henny Wijnen, Robertas Bunevicius, Anneloes van Baar, and Victor Pop. Validation of the Edinburgh Depression Scale during pregnancy. Journal of psychosomatic research, 70(4):385-389, apr 2011. ISSN 1879-1360 (Electronic). doi: 10.1016/j.jpsychores.2010.07.008.

[23] Jeannette Milgrom and Alan W Gemmill. Screening for perinatal depression. Best practice \& research. Clinical obstetrics \& gynaecology, 28(1):13-23, jan 2014. ISSN 1532-1932 (Electronic). doi: 10.1016/j.bpobgyn.2013.08. 014.

[24] Christine Rubertsson, Karin Borjesson, Anna Berglund, Ann Josefsson, and Gunilla Sydsjo. The Swedish validation of Edinburgh Postnatal Depression Scale (EPDS) during pregnancy. Nordic journal of psychiatry, 65 (6):414-418, dec 2011. ISSN 1502-4725 (Electronic). doi: 10.3109/08039488.2011.590606.

[25] R Core Team. R: A language and environment for statistical computing. R Foundation for Statistical Computing, Vienna, Austria., 2016.

[26] Robert C Gentleman, Vincent J Carey, Douglas M Bates, Ben Bolstad, Marcel Dettling, Sandrine Dudoit, Byron Ellis, Laurent Gautier, Yongchao Ge, Jeff Gentry, Kurt Hornik, Torsten Hothorn, Wolfgang Huber, Stefano Iacus, Rafael Irizarry, Friedrich Leisch, Cheng Li, Martin Maechler, Anthony J Rossini, Gunther Sawitzki, Colin Smith, Gordon Smyth, Luke Tierney, Jean Y H Yang, and Jianhua Zhang. Bioconductor: open software development for computational biology and bioinformatics. Genome biology, 5(10):R80, 2004. ISSN 1474-760X (Electronic). doi: 10.1186/gb-2004-5-10-r80.

[27] Martin J Aryee, Andrew E Jaffe, Hector Corrada-Bravo, Christine Ladd-Acosta, Andrew P Feinberg, Kasper D Hansen, and Rafael A Irizarry. Minfi: a flexible and comprehensive Bioconductor package for the analysis of Infinium DNA methylation microarrays. Bioinformatics, 30(10):1363-1369, may 2014. ISSN 1367-4803. URL http://dx.doi.org/10.1093/bioinformatics/btu049.

[28] Wolfgang Huber, Vincent J Carey, Robert Gentleman, Simon Anders, Marc Carlson, Benilton S Carvalho, Hector Corrada Bravo, Sean Davis, Laurent Gatto, Thomas Girke, Raphael Gottardo, Florian Hahne, Kasper D Hansen, Rafael A Irizarry, Michael Lawrence, Michael I Love, James MacDonald, Valerie Obenchain, Andrzej K Oles, Herve Pages, Alejandro Reyes, Paul Shannon, Gordon K Smyth, Dan Tenenbaum, Levi Waldron, and Martin Morgan. Orchestrating high-throughput genomic analysis with Bioconductor. Nature methods, 12(2):115-121, feb 2015. ISSN 1548-7105 (Electronic). doi: 10.1038/nmeth.3252. 
medRxiv preprint doi: https://doi.org/10.1101/2020.03.05.20027847; this version posted March 8, 2020. The copyright holder for this preprint

(which was not certified by peer review) is the author/funder, who has granted medRxiv a license to display the preprint in perpetuity.

It is made available under a CC-BY-NC-ND 4.0 International license .

A PREPRINT - FEBRUARY 21, 2020

[29] Eugene Andres Houseman, William P Accomando, Devin C Koestler, Brock C Christensen, Carmen J Marsit, Heather H Nelson, John K Wiencke, and Karl T Kelsey. DNA methylation arrays as surrogate measures of cell mixture distribution. BMC bioinformatics, 13:86, may 2012. ISSN 1471-2105 (Electronic). doi: 10.1186/1471-2105-13-86.

[30] Jeffrey T Leek, W Evan Johnson, Hilary S Parker, Andrew E Jaffe, and John D Storey. The sva package for removing batch effects and other unwanted variation in high-throughput experiments. Bioinformatics (Oxford, England), 28(6):882-883, mar 2012. ISSN 1367-4811. doi: 10.1093/bioinformatics/bts034. URL https: //www.ncbi.nlm.nih.gov/pubmed/22257669https://www.ncbi.nlm.nih.gov/pmc/PMC3307112/.

[31] Xavier Robin, Natacha Turck, Alexandre Hainard, Natalia Tiberti, Frédérique Lisacek, Jean-Charles Sanchez, and Markus Müller. pROC: an open-source package for R and S+ to analyze and compare ROC curves. $B M C$ bioinformatics, 12:77, 2011.

[32] Jerry Guintivano and Zachary A Kaminsky. Role of epigenetic factors in the development of mental illness throughout life. Neuroscience research, 102:56-66, jan 2016. ISSN 1872-8111 (Electronic). doi: 10.1016/j. neures.2014.08.003.

[33] Douglas F Levinson, George S Zubenko, Raymond R Crowe, Raymond J DePaulo, William S Scheftner, Myrna M Weissman, Peter Holmans, Wendy N Zubenko, Sandra Boutelle, Kathleen Murphy-Eberenz, Dean MacKinnon, Melvin G McInnis, Diana H Marta, Philip Adams, Stephanie Sassoon, James A Knowles, Jo Thomas, and Jennifer Chellis. Genetics of recurrent early-onset depression (GenRED): design and preliminary clinical characteristics of a repository sample for genetic linkage studies. American journal of medical genetics. Part B, Neuropsychiatric genetics : the official publication of the International Society of Psychiatric Genetics, 119B(1):118-130, may 2003. ISSN 1552-4841 (Print). doi: 10.1002/ajmg.b.20009.

[34] D Mehta, D J Newport, G Frishman, L Kraus, M Rex-Haffner, J C Ritchie, A Lori, B T Knight, E Stagnaro, A Ruepp, Z N Stowe, and E B Binder. Early predictive biomarkers for postpartum depression point to a role for estrogen receptor signaling. Psychological medicine, 44(11):2309-2322, aug 2014. ISSN 1469-8978 (Electronic). doi: $10.1017 / \mathrm{S} 0033291713003231$.

[35] Alexander Hein, Claudia Rauh, Anne Engel, Lothar Haberle, Ulf Dammer, Franziska Voigt, Peter A Fasching, Florian Faschingbauer, Pascal Burger, Matthias W Beckmann, Johannes Kornhuber, and Tamme W Goecke. Socioeconomic status and depression during and after pregnancy in the Franconian Maternal Health Evaluation Studies (FRAMES). Archives of gynecology and obstetrics, 289(4):755-763, apr 2014. ISSN 1432-0711 (Electronic). doi: 10.1007/s00404-013-3046-y.

[36] Heather A Bennett, Adrienne Einarson, Anna Taddio, Gideon Koren, and Thomas R Einarson. Prevalence of depression during pregnancy: systematic review. Obstetrics and gynecology, 103(4):698-709, apr 2004. ISSN 0029-7844 (Print). doi: 10.1097/01.AOG.0000116689.75396.5f. 